\title{
An Experimental Test of Strategic Trade Policy
}

\author{
Dirk Engelmann \\ Hans-Theo Normann
}

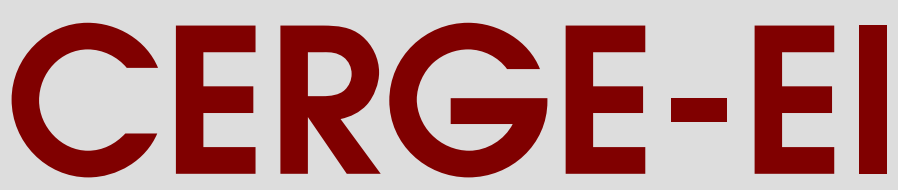

Charles University Center for Economic Research and Graduate Education Academy of Sciences of the Czech Republic Economics Institute 


\title{
An Experimental Test of Strategic Trade Policy*
}

\author{
Dirk Engelmann ${ }^{\dagger}$ \\ CERGE-EI, Charles University, Prague, and Academy of Sciences of the Czech Republic \\ Hans-Theo Normann \\ Royal Holloway, University of London
}

June 16, 2003

\begin{abstract}
In this experiment, we analyze the model of strategic trade policy proposed by Brander and Spencer (1985). Governments can choose whether or not to subsidize domestic firms. Firms compete in a Cournot duopoly, and they know the subsidy decisions when choosing output. Although the theoretical prediction is that firms are subsidized, it turns out that governments only rarely subsidize in experimental markets. Not subsidizing is rational given our observation that firms do not play according to the subgame perfect equilibrium when subsidies are given.

V tomto experimentu analyzujeme model strategické obchodní politiky navržené Branderem a Spencrem (1985). Vlády mohou zvolit, zda subvencovat domácí firmy nebo ne. Firmy soutěží v Cournotově duopolu a znají velikost subvence při volbě objemu výroby. Ačkoli teorie předpokládá, že firmy jsou subvencované, ukazuje se, že na experimentálních trzích podporují vlády firmy jen zřídka. Vzhledem k našemu pozorování, že firmy nehrají podle subherně-ideálních strategií v případě zisku subvence, strategie nesubvencovat je racionální.
\end{abstract}

JEL Classification numbers: F13, L13, C92.

Keywords: Commercial policy, experimental economics, strategic commitment.

\footnotetext{
*We are grateful to Steffen Huck and Kresimir Zigic for helpful comments. Financial support by the Deutsche Forschungsgmeinschaft (through SFB 373 and grant No. EN 459/1-1), the DGZ-DekaBank and the CERGE-EI foundation (through an ESC-postdoctoral fellowship) is gratefully acknowledged.

†CERGE-EI, P.O.Box 882, Politickych veznu 7, 11121 Prague 1, Czech Republic, dirk.engelmann@cerge-ei.cz.

$\ddagger$ Department of Economics, Royal Holloway, University of London, Egham, Surrey TW20 0EX, UK, Fax: +44 1784439534 , e-mail: hans.normann@rhul.ac.uk.
} 


\section{Introduction}

The model of strategic trade policy as proposed initially by Brander and Spencer (1985) is without a doubt one of the most influential ideas in both recent trade theory and trade policy. However, the empirical validity of the model of strategic trade policy is still a much debated topic. A fundamental problem with most empirical studies is that they usually make use of calibration models rather than field data estimation models (see e.g., Baldwin and Krugman, 1988; Dixit, 1988; Krishna et al., 1994). The assumptions underlying the calibration methods are sometimes ad hoc and the results may therefore not be particularly robust. Brander (1995, p.1438) concludes that the importance of these "calibration exercises ... is for the light they shed on the theoretical structure of strategic trade policy, rather than because of their empirical significance." Given this methodological disclaimer, "it is safe to say that the jury is still out for the empirical evaluation of trade policies" (Maggi, 1996, p.237).

In this paper, we report results from an experiment designed to test strategic trade policy in laboratory markets. The experimental approach has been successfully applied in almost all areas of economics, including applied and policy-orientated fields like industrial organization, labor markets, public finance and macroeconomics (see Davis and Holt, 1993, for a survey). Previous experiments on issues in international economics include the studies by Noussair et al. (1995) on the Ricardian trade theory, by Noussair et al. (1997) on the principles of exchange rate determination, and by Ansic (1995) on trade hysteresis.

The experimental approach has several advantages compared to a field-data analysis of strategic trade policy. In the laboratory, we can design markets exactly according to the assertions of the theory. By doing so, we can provide conditions suited to making the theory work well. In our case, this amounts to designing the markets precisely according to the original Brander and Spencer (1985) framework, although in a simplified manner. A second advantage concerns interpretation of the data. In field markets, there are often market dynamics or other external factors that influence the market outcome and which sometimes make the interpretation of the data with respect to the effect of the policy difficult. In the laboratory, there are no such uncontrolled changes of the market determinants. As the cost and demand structure of the market are given by design, the data can unambiguously be interpreted with respect to the underlying theoretical model. A third advantage from running an experiment is that we can observe market outcomes 
for various combinations of government decisions. In the field, there is typically only one set of government decisions under which a certain market can be analyzed. ${ }^{1}$ In the experiment, we can analyze the impact of several different sets of subsidy decisions on firm behavior. Given these three points, we believe that an experimental investigation can lead to useful insights.

The experimental approach may also have disadvantages. Plott (1982, p.1522) lists, and rejects, the most common ones. In connection with strategic trade policy, an obvious and important scepticism is that decision making in the field is arguably much more complex than that in laboratory markets. Decision makers in the field - here governments and firms' managers - decide in a very rich economic, social, and political environment. In the laboratory, all these factors are missing, and subjects decide in a very simplified market environment. This objection is to be taken very seriously. However, it appears to us that the simplified environment of the laboratory may also be an advantage. If student subjects (who indeed become the decision makers in the field later anyway) do not decide according to the prediction in the experimental markets, can we expect the decision makers in the field to be closer? Should not the contrary be true, since, compared to the pure incentive structure as replicated in the experiment, the additional elements of a richer environment would cause further deviations from the theoretical prediction by blurring the incentives? We think that studying both the simple experimental environment and the rich environment in the field can lead to important insights. The experimental evidence should be seen as complementary to the existing empirical literature on strategic trade policy.

We study a simple Cournot duopoly framework, matching the requirements of the Brander and Spencer (1985) theory. There are two countries, each consisting of a government and a firm, and the firms export a homogenous good to a third country. Governments simultaneously decide whether or not to subsidize their firm. Then, knowing the subsidy decisions of both governments, the firms play a Cournot duopoly. The criticism has been made (Krugman, 1993) that the appropriate strategic trade policy is highly sensitive to details of the market structure. In particular, the policy conclusions derived from the Brander and Spencer (1985) setup are reversed if the product market competition is characterized by strategic complementarity

\footnotetext{
${ }^{1}$ Grossman (1990) pointed out that field studies of strategic trade policy often focus on successful cases, leading to a sample-selection bias.
} 
rather than strategic substitutability (Eaton and Grossman, 1986). By employing a standard Cournot duopoly, we arguably give the Brander and Spencer (1985) prediction the best shot.

The payoffs in the two-stage game are derived from linear demand and cost schedules. The payoffs in the experiment are exchanged into Deutschemarks at the end of the experiment. That is, there are real monetary incentives and participants face precisely the incentives the theory asserts. All else equal, a firm has an incentive to increase its quantity when it is subsidized and to decrease its quantity when the other firm is subsidized. This implies that governments are in a prisoners' dilemma situation: positive subsidies occur in equilibrium but they lead to a Pareto inferior outcome.

Our main question in this experiment is whether or not governments actually subsidize their firms. That is, at a general level, we are simply testing the validity of the Brander and Spencer (1985) prediction in experimental markets. At a more specific level, we are trying to gain insight into some peculiarities underlying the theory. The core of the Brander and Spencer (1985) theory is that subsidies work as a commitment device in international competition. This, in turn, requires that given the subsidy decisions, firms choose the subgame perfect output quantities in the second stage. However, Brander (1995, p.1449) suggests that it is not certain that such subgame perfect decisions will always occur: "We might reasonably believe that players can find a Nash equilibrium in a simple one-shot game. ... Expecting real players to incorporate a sequential rationality requirement such as subgame perfection in simple games is asking a lot more, and experimental subjects have a much harder time with this requirement." If output decisions at the firm level are not subgame perfect, the rational choice of the governments may also differ from the equilibrium prediction.

In addition, even if firms make subgame perfect decisions, there is still the possibility of cooperation at the government level. As mentioned, governments are in a prisoners' dilemma situation. While the Brander and Spencer (1985) theory is a static one, there is often repeated interaction among firms and governments in the field. Brander (1995) points out that with repeated interaction the results in the trade policy game might differ as a consequence of possible cooperation. Therefore, an interesting design issue concerns the nature of the interaction between the participants in the experiment. We deal with this problem by allowing for two types of interaction. In one treatment type, two countries (that is, two government-firm pairs) stay 
together as one interaction group for the entire course of the experiment. In a second type, we simulate one-shot interaction by randomly rematching the countries in every period (the government-firm pairs are fixed in all treatments). As a consequence, we can control for the impact of repeated interaction.

In all, we consider our experiment not simply as an attempt to confirm or reject the theory. It may also give rise to new interpretations and modifications of the theory itself.

The remainder of the paper is organized as follows: Section 2 presents the underlying theory and the experimental design, Section 3 reports the experimental results, and Section 4 concludes.

\section{Theory and Experimental Design}

In line with the Brander and Spencer (1985) model, we use linear demand and cost functions for our experiment. More specifically, inverse demand was

$$
p\left(q_{1}, q_{2}\right)=\max \left\{60-q_{1}-q_{2}, 0\right\}
$$

where $q_{i}, i=1,2$, denotes firm $i$ 's output. In order to avoid negative profits, we set constant marginal costs equal to zero.

What is the prediction for this setup? Consider the second stage first. Government subsidies are linear in quantity. The constant marginal subsidies are denoted by $s_{i}, i=1,2$, and are known to both firms. Firms' profits are

$$
p\left(q_{1}, q_{2}\right) \cdot q_{i}+s_{i} \cdot q_{i}=\left(\max \left\{60-q_{1}-q_{2}, 0\right\}+s_{i}\right) \cdot q_{i} .
$$

This yields

$$
q_{i}=\frac{60+2 s_{i}-s_{j}}{3}, i=1,2 ; j \neq i
$$

as equilibrium quantities.

Then consider the government decision at the first stage. Governments decide simultaneously about $s_{1}$ and $s_{2}$, respectively. Their objective is to maximize welfare in their respective countries. There is no domestic consumption and exports go to a third country, so welfare is equal to net profits, $p q_{i}$. Maximizing 
this expression yields governments' equilibrium subsidies. Governments choose $s_{1}^{*}=s_{2}^{*}=12$ which yields $q_{1}^{*}=q_{2}^{*}=24$. By contrast, if governments choose $s_{1}=s_{2}=0$, firms produce $q_{1}=q_{2}=20$ (the Cournot equilibrium quantities of the duopoly without governments).

While this calculation is a straightforward exercise for trained economists, in the laboratory, this twostage game is of considerable complexity. Note that, for every $\left(s_{1}, s_{2}\right)$ combination, there is a different subgame with different subgame-perfect outputs. Such complexity might overload subjects which in the end may lead to erratic decisions. Therefore, we simplified the design as far as possible, maintaining all features of the original model.

We restricted the governments' strategy sets to only two choices corresponding to $s_{i}=0$ (no subsidy) and $s_{i}=12$ (the equilibrium subsidy). ${ }^{2}$ This reduces the number of possible firm subgames to four. Restricting governments' choices to polar cases also makes the strategic impact of the subsidy decision more transparent.

We also restricted firms' strategy sets. As noted above, if both governments choose $s_{1}=s_{2}=0$, firms should, from a normative point of view, produce $q_{1}=q_{2}=20$. If both governments choose $s_{1}=s_{2}=12$, firms' optimal choice is $q_{1}=q_{2}=24$. Finally, asymmetric choices of $s_{i}=12$ and $s_{j}=0$ imply $q_{i}=28$ and $q_{j}=16$. In principle, we let subjects choose from the set of these four quantities. An exception is that we decided to include the quantity 15 rather than 16 as the first element in the strategy set, so firms' strategy set was $\{15,20,24,28\} .{ }^{3}$ The reason is a conceptual problem. It is well known that Cournot games with a discretized strategy space give rise to multiple equilibria because best replies are not unique (Holt, 1985). With $q_{i}=16$, we do get multiple equilibria while, with $q_{i}=15$, this problem is resolved and we get a unique equilibrium in all four subgames. Furthermore, note that $q_{i}=15$ corresponds to the symmetric cartel output.

\footnotetext{
${ }^{2}$ The reader will note that $s_{i}=15$ rather than $s_{i}=12$ is the government's best reply to $s_{j}=0$. However, the restricted strategy set $\{0,12\}$ simplifies the design while subsidizing is still a dominant strategy for governments.

${ }^{3}$ Since the size of the quantities $\{15,20,24,28\}$ is entirely meaningless to subjects (note that they did not know the model), we labelled the strategies $\{1,2,3,4\}$ instead. However, since the reader is familiar with the model and the equilibrium values, we will refer to quantities $\{15,20,24,28\}$ throughout the paper.
} 
This reduced game was presented to subjects by payoff tables rather than by the model's parameters and payoff functions. They are reproduced in Tables 1-4. In principle, they are derived from the above linear model.

\begin{tabular}{|c||c|c|c|c|}
\hline Output & 15 & 20 & 24 & 28 \\
\hline \hline 15 & 450,450 & 380,500 & 310,510 & 260,480 \\
\hline 20 & 500,380 & 400,400 & 320,380 & 240,340 \\
\hline 24 & 510,310 & 380,320 & 290,290 & 200,230 \\
\hline 28 & 480,260 & 340,240 & 230,200 & 120,120 \\
\hline
\end{tabular}

Table 1: Firms' payoffs if neither firm is subsidized

Consider firms' payoff tables first. If both governments choose $s_{i}=0$, the payoff matrix of a firm is as in Table 1. It is easily checked that the entries result from rounding the profit $\left(60-q_{1}-q_{2}\right) \cdot q_{i}$ to multiples of $10{ }^{4}$ Tables 2 and 3 involve subsidies which were computed as follows. We normalized the subsidy such that, with $q_{i}=15$, the subsidy is zero. ${ }^{5}$ More precisely, the formula for the subsidy was $\left(q_{i}-15\right) \cdot 12$ (again subsequently rounded to multiples of 10 ). That is, with $q_{i}=20$ the subsidy is 60 , with $q_{i}=24$ the subsidy is 110 , and with $q_{i}=28$ the subsidy 160 . If both governments choose $s_{i}=12$, the relevant firm matrix is the one in Table 2 where the appropriate subsidy is added for both firms. If one government chooses $s_{i}=0$ while the other one chooses $s_{j}=12$, the matrix shown in Table 3 results. Another table given to subjects (not reproduced here) gave the payoffs where the first firm was subsidized while the second was not. This table is somewhat redundant but it might have helped subjects to understand the game.

Table 4 is the governments' profit table. Recall that in theory governments are supposed to maximize welfare. Following the generally accepted "induced value approach" of Smith (1982), governments' payoffs are according to welfare in their respective countries. Since exports are into a third country, welfare is simply

\footnotetext{
${ }^{4}$ To obtain unique best replies, we deviated from this rule in one case by rounding 315 to 310.

${ }^{5}$ If the subsidy was simply $12 q_{i}$, firms' profits would increase dramatically through subsidies. This would imply that the strategic incentives become very small compared to the total payoffs. Without the normalization, governments could substantially increase efficiency through subsidizing, which again might dominate the strategic incentives (see also the design of our treatment FixedPoLICY* below).
} 


\begin{tabular}{|c||c|c|c|c|}
\hline Output & 15 & 20 & 24 & 28 \\
\hline \hline 15 & 450,450 & 380,560 & 310,620 & 260,640 \\
\hline 20 & 560,380 & 460,460 & 380,490 & 300,500 \\
\hline 24 & 620,310 & 490,380 & 400,400 & 310,390 \\
\hline 28 & 640,260 & 500,300 & 390,310 & 280,280 \\
\hline
\end{tabular}

Table 2: Firms' payoffs if both firms are subsidized

\begin{tabular}{|c||c|c|c|c|}
\hline Output & 15 & 20 & 24 & 28 \\
\hline \hline 15 & 450,450 & 380,560 & 310,620 & 260,640 \\
\hline 20 & 500,380 & 400,460 & 320,490 & 240,500 \\
\hline 24 & 510,310 & 380,380 & 290,400 & 200,390 \\
\hline 28 & 480,260 & 340,300 & 230,310 & 120,280 \\
\hline
\end{tabular}

Table 3: Firms' payoffs if the column firm is subsidized, while the row firm is not

the net profit of the firm. Note that this implies that the subsidies have no direct effect on the payoffs of governments. ${ }^{6}$ They matter only indirectly as they change incentives for the firms. As a consequence, there is just one payoff table for governments which depends only on firms' outputs and not on the subsidy decision.

Note further that firms' profits and governments' payoffs were of different magnitudes. More precisely, firms' (net) profits were divided by 5 to obtain governments' payoffs. This was done in order to avoid payoff comparisons within a government-firm pair. Such inter-personnel payoff comparisons might trigger behavioral patters we cannot control for and they might bias the results. In order to equalize average payments of the governments and firms, we used different (commonly known) exchange rates when converting the experimental payments into Deutschemarks (see below).

Analyzing these tables shows that the game can be solved by iterated elimination of dominated strategies. The subgame perfect output choices coincide, of course, with those derived above. With $s_{1}=s_{2}=0$, firms produce 20 each; with $s_{1}=s_{2}=12$, firms produce 24 each; $s_{i}=12$ and $s_{j}=0$ imply $q_{i}=28$ and

\footnotetext{
${ }^{6}$ If governments actually had to pay the subsidy (e.g., from an initial capital provided by the experimentator) this would reduce the incentive to subsidize production. The Brander and Spencer prediction would no longer be valid.
} 


\begin{tabular}{|c||c|c|c|c|}
\hline Output & 15 & 20 & 24 & 28 \\
\hline \hline 15 & 90,90 & 76,100 & 62,102 & 52,96 \\
\hline 20 & 100,76 & 80,80 & 64,76 & 48,68 \\
\hline 24 & 102,62 & 76,64 & 58,58 & 40,46 \\
\hline 28 & 96,52 & 68,48 & 46,40 & 24,24 \\
\hline
\end{tabular}

Table 4: Governments' payoff, dependent on firms' output

$q_{j}=15$. Analyzing the governments' payoffs resulting from these decisions shows that the equilibrium at the government level is to subsidize.

We now turn to further issues of the experimental design. Subjects continued to act either as a government or as a firm for the entire course of the experiment. All five payoff tables and the instructions sheets were, however, given to all subjects before they knew which role they would play. Government-firm pairs remained fixed over all periods.

Our two treatment variables concerned the labelling of subsidies and the form of interaction between the government-firm pairs. The term "subsidize" may not be a neutral term to our participants. On the one hand, from economics classes, subjects might be biased against subsidies because they were taught that free trade is the best policy. On the other hand, they may also be biased in favor of subsidies because "head to head" and globalization rhetorics makes them think they should adopt an active policy. We therefore labelled these actions in one treatment condition "don't subsidize" and "subsidize," respectively, and in a second treatment condition we labelled the two actions "Policy A" and "Policy B" without further describing the policy. Below, we will distinguish these two treatment conditions with the labels SUBSIDY and Policy. (On the effects of different labels in market experiments see, e.g., Hoffman et al., 1994 and Francicosi et al., 1995.)

Our second treatment variable concerned the form of interaction between government-firm pairs. The first treatment condition, labelled FIXED, has fixed duopoly pairs playing over all periods. In the second treatment condition, labelled RANDOM, duopolies were rematched in every period. Since two governmentfirm pairs might interact again at a later stage, this is no perfect simulation of one-shot encounters. Subject pairs cannot, however, recognize whether they have interacted before. While the Brander and Spencer 


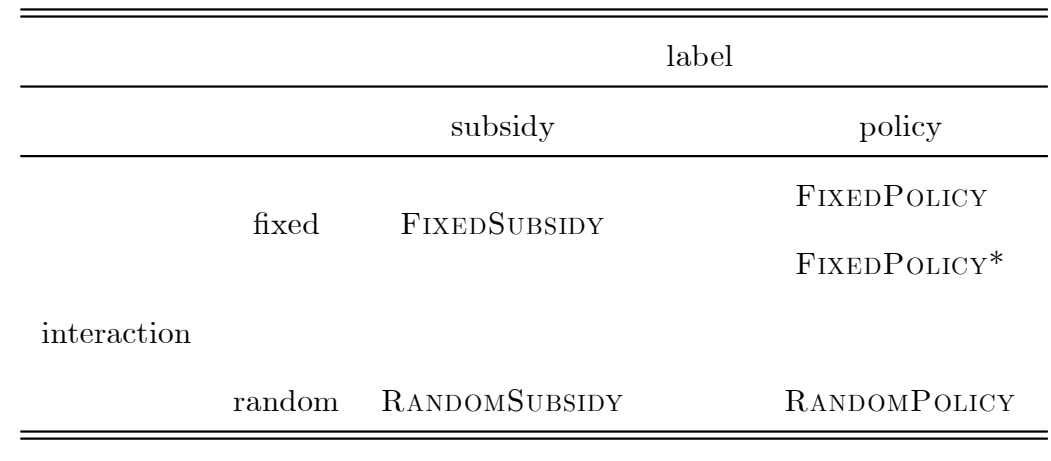

Table 5: The treatments

(1985) theory is formulated as a one-shot interaction, in the field the interaction might rather be repeated. Hence our RANDOM treatment closely maps the theoretical model, whereas our FixED treatment arguably better reflects field settings. Together with the treatment variable "label," we obtain the $2 \mathrm{x} 2$ design displayed in Table 5 .

After running the sessions for these four treatments, we decided to introduce a fifth treatment. This treatment is called FixedPolicy*. The same motivation which led us to normalize the subsidy (see footnote 5 above) applies here. In line with the Brander and Spencer (1985) model, the subsidies in our experiments are donations from the governments to the firms that do not affect welfare and therefore the governments' payoffs. This may be problematic since governments could choose to subsidize to directly increase firms' payoffs out of generosity rather than for strategic reasons. ${ }^{7}$ This implies that if firms do not play the subgame perfect equilibrium, it is not entirely clear whether governments subsidize for strategic or altruistic reasons or due to concerns for efficiency, which both might be more relevant in the laboratory than in the field. Therefore we conducted the control treatment FixEDPOLICY*. This treatment differed from FixedPOLICY by a reduction of the payoff of a subsidized firm by 80 points for any combination of quantity decisions. This leaves the strategic incentives for firms and governments unchanged but eliminates altruistic subsidies: subsidies only increase the firms' payoff for quantities 24 and 28 , whereas they reduce firms' payoff for quantities 15 and 20. We chose treatment FIXEDPOLICY as a point of departure for two reasons. First, a negative subsidy seems rather strange, whereas a policy may plausibly have negative effects

\footnotetext{
${ }^{7}$ In treatment FixedPolicy, there was one striking example of this behavior. One government chose "Policy A" in all ten periods while the other goverment chose "Policy B" in seven periods. Firms, however, entirely ignored the strategic incentives and colluded on quantity 15 in all periods except the last.
} 
for small quantities and positive for large quantities. Therefore the POLICY frame seems more appropriate. Second, collusive behavior of the firms and thus altruistic subsidizing seems more likely in the case of FIXED matching.

For all treatments, we conducted two sessions with 12 subjects participating in each session. In treatments with random matching, all six government-firm pairs interacted; with fixed matching, three groups of four subjects interacted but subjects could not tell with whom they were matched.

The markets lasted for 10 periods. At the beginning of each period, governments had to choose whether or not to subsidize their firms (or alternatively, choose "Policy B" or "Policy A"). The subsidy decisions were made public to all four participants on computer screens afterwards. Then firms had to choose outputs. After that, output decisions were revealed to all four participants and the resulting payoffs were disclosed individually.

Exchange rates were such that governments got one Deutschemark for every 40 "points" and firms got one Deutschemark for every 200 "points". Average earnings were DM 19.30. Sessions lasted between 70 and 90 minutes. The experiments were conducted in the experimental computer lab of Humboldt University, Berlin. In total, 120 students, mainly from the Department of Business Administration and Economics, participated. For the computerized experiment we used the software tool kit $z$-Tree, developed by Fischbacher (1999). Translated instructions are provided in the Appendix.

\section{Results}

We start with the governments' decisions at stage one. Table 6 contains the "subsidize" 8 decisions in the five treatments over the ten periods. In total, roughly $50 \%$ of the government decisions were "subsidize" decisions. Based on a binomial test, we cannot reject the hypothesis that "subsidize" / "don't subsidize" decisions are equiprobable for all treatments taken together. Considering the treatments individually, in RandomSubsidy and FiXedPolicy*, there are significantly more "don't subsidize" decisions (binomial test, 5\%-level).

\footnotetext{
${ }^{8}$ For simplicity, we use the term "subsidize" also for "Policy B" decisions whenever this does not create confusion.
} 


\begin{tabular}{lccccccccccc}
\hline \hline Period & 1 & 2 & 3 & 4 & 5 & 6 & 7 & 8 & 9 & 10 & Total \\
\hline \hline RANDOMSubsidy & 11 & 7 & 7 & 4 & 4 & 3 & 2 & 4 & 2 & 3 & $47(120)$ \\
RANDOMPOLICY & 8 & 8 & 6 & 5 & 8 & 10 & 7 & 7 & 5 & 6 & $70(120)$ \\
FiXedSubsidY & 5 & 6 & 7 & 6 & 7 & 5 & 9 & 7 & 5 & 5 & $62(120)$ \\
FixedPOLICY & 9 & 4 & 5 & 6 & 6 & 7 & 7 & 5 & 5 & 5 & $59(120)$ \\
\hline$\sum$ & 33 & 25 & 25 & 21 & 25 & 25 & 25 & 23 & 17 & 19 & $238(480)$ \\
\hline \hline FixedPOLICY* & 3 & 5 & 4 & 3 & 4 & 4 & 3 & 5 & 5 & 4 & $40(120)$ \\
\hline \hline
\end{tabular}

Table 6: Number of "subsidize" choices across periods (maximum: 12)

Importantly, the "subsidize" decisions were not positively correlated with time in any treatment. In RANDOMSUBSIDY and in all treatments taken together, there was a significant negative time trend (at the $1 \%$ and the $5 \%$ level, respectively). A similar result is that there is an end-game effect in all treatments in the sense that there are fewer "subsidize" decisions in the last period (last two periods) compared to periods 1-9 (1-8). This end-game effect is significant at the $1 \%$ level for the RANDOM treatments in the last two periods (OLS with period 10/periods 9 and 10 as explanatory variables). ${ }^{9}$

What was the impact of the treatments on the governments' decisions? Based on the "subsidize" decisions, our two treatment variables do not lead to significant differences. That is, both the RANDOM versus the FiXED treatments and the SubSIDY versus the POLICY treatments are not significantly different (binomial test, 5\%-level). As we argued above, there are possible reasons for effects in either direction concerning the Subsidy versus POLICY labelling. So, ex post it may appear not to be surprising that there are no differences. The result that RANDOM versus Fixed matching does not have an impact is, however, quite surprising. In comparable prisoners' dilemma experiments (e.g., Cooper et al., 1996), there is typically significantly more cooperation with fixed matching. This suggests that there should have been fewer "subsidize" decisions in the FiXeD treatments, but we do not observe such an effect. We cannot, however, preclude that there would have been such an effect if we had conducted substantially more than

\footnotetext{
${ }^{9}$ Note that this end game effect is in opposite direction to those effects typically observed in repeated games. We would, however, not interpret this in a way that governments become more cooperative towards the end, but rather that they learn that subsidizing does not pay, as outlined below.
} 
10 periods.

The only significant treatment effect in the data is that FIXEDPOLICY* has significantly fewer "Policy B" (i.e., "subsidize") decisions than FixedPolicy (binomial test, 5\%-level). The number of decisions to subsidize in the control treatment FiXEDPOLICY* is also substantially lower than in the other treatments (though these figures cannot, of course, be directly compared). Thus, it seems that some of the subsidy choices are driven not by strategic considerations but by generosity of the governments towards the firms. This implies that the motivation of governments to "subsidize" is presumably less well captured by the Brander and Spencer (1985) theory than the numbers of "subsidize" choices in the four main treatments suggest.

To summarize the data on the "subsidize" decisions, there are few such decisions and there is no indication of a learning trend towards the equilibrium. No individual treatment suggests a different interpretation of the data. We conclude that the experimental data do not support the Brander and Spencer (1985) theory at the government level.

We now turn to the second stage, the output decisions of the firms. Table 7 shows the average industry output levels by treatment and by subgame in the second half of the experiment. The table also contains the average individual output in the asymmetric subgames. Industry output roughly matches the prediction in all treatments. Industry output is below the prediction in the B/B subgames for all treatments, and output is also lower than predicted, at least for the FIXED treatments, in the A/A subgames. In the asymmetric subgames, output is sometimes above, sometimes below the prediction. In all, the theory seems to predict well as all observed values for mean industry output are within one standard deviation of the prediction.

The most interesting aspect of the data are the individual output decisions in the asymmetric subgames. The average output of the subsidized firm is substantially lower than predicted, while that of the firm that is not subsidized substantially exceeds the prediction. Except for treatment RANDOMSuBsidy, subsidized firms chose an average output of 24 or below. The predicted difference in output between the firm which is subsidized and the one which is not is 13 . In RANDOMSUBSIDY, the difference is only 7.5 and even smaller in the other treatments. In FIXEDPOLICY, it is as small as 2.86. These deviations are possibly based on fairness considerations, in particular on inequality aversion. Fehr and Schmidt (1999) and Bolton and 


\begin{tabular}{|c|c|c|c|c|c|c|}
\hline & ТнгОву & RANDOM & RANDOM & FIXED & FIXED & FIXED \\
\hline & & SuBsidy & Policy & Subsidy & Policy & PoliCY* \\
\hline \multirow[t]{3}{*}{$\mathrm{A} / \mathrm{A}$} & 40.00 & 40.61 & 40.33 & 37.00 & 37.75 & 37.23 \\
\hline & & $(3.62)$ & $(5.59)$ & $(5.83)$ & $(7.08)$ & $(6.97)$ \\
\hline & & \#18 & $\# 6$ & $\# 7$ & $\# 8$ & \#13 \\
\hline \multirow[t]{3}{*}{$\mathrm{A} / \mathrm{B}$} & 43.00 & 45.30 & 43.54 & 40.67 & 42.60 & 43.23 \\
\hline & & $(3.74)$ & $(4.54)$ & $(6.14)$ & $(7.10)$ & $(6.84)$ \\
\hline & & $\# 10$ & \#13 & $\# 15$ & $\# 15$ & $\# 13$ \\
\hline $\mathrm{A}$ & 15.00 & 18.90 & 19.85 & 17.67 & 19.87 & 19.85 \\
\hline B & 28.00 & 26.40 & 23.69 & 23.00 & 22.73 & 23.38 \\
\hline \multirow[t]{3}{*}{$\mathrm{B} / \mathrm{B}$} & 48.00 & 46.00 & 47.26 & 47.50 & 44.00 & 47.00 \\
\hline & & $(3.87)$ & $(4.95)$ & $(6.07)$ & $(6.80)$ & $(6.98)$ \\
\hline & & $\# 2$ & \#11 & \#8 & $\# 7$ & $\# 4$ \\
\hline
\end{tabular}

Table 7: Average observed industry output in subgames, standard deviation in parentheses, \# number of observations

Ockenfels (2000) have recently extended the general economic paradigm (maximization of own well being) to allow for inequality aversion. These theories (see Engelmann and Strobel, 2002, for an experimental comparison of these two theories) are able to rationalize a number of phenomena in experiments that the traditional theory failed to do so. Inequality aversion is a likely explanation for the deviation from the subgame perfect outputs in the asymmetric subgames.

Note that in our setup, the equalization of profits can be obtained at a relatively low cost. In equilibrium, the non-subsidized firm $i$ would produce $q_{i}=15$, while the subsidized firm $j$ would produce $q_{j}=28$. This implies payoffs of 260 for $i$ and 640 for $j$ (see Table 3). If $i$ deviates to 20, the payoffs are 240 and 500 . Thus, at a cost of 20, $i$ can reduce the negative inequality by 120 (from 380 to 260). On the other hand, by deviating from 28 to $24, j$ can reduce the positive inequality from 380 to 310 at a cost of 20 (if $i$ chooses 15) or from 260 to 170 at a cost of 10 (if $i$ chooses 20). If $j$ chooses $24, i$ can even gain 10 and reduce the 


\begin{tabular}{|c|c|c|c|c|c|c|c|}
\hline & & \multirow{2}{*}{ all } & RANDOM & RANDOM & FIXED & FIXED & FIXED \\
\hline & & & SUbsidy & Policy & Subsidy & Policy & POLICY* \\
\hline \multirow{3}{*}{$\mathrm{A} / \mathrm{A}$} & (a) & 99 & 27 & 12 & 17 & 15 & 28 \\
\hline & (b) & 38 & 20 & 2 & 7 & 4 & 5 \\
\hline & (c) & 117 & 47 & 12 & 22 & 15 & 21 \\
\hline \multirow{4}{*}{$\mathrm{A} / \mathrm{B}$} & (a) & 124 & 19 & 26 & 24 & 31 & 24 \\
\hline & (b) & 16 & 2 & 5 & 1 & 5 & 3 \\
\hline & (d) & 44 & 4 & 8 & 12 & 12 & 8 \\
\hline & (e) & 43 & 8 & 12 & 5 & 11 & 7 \\
\hline \multirow{3}{*}{$\mathrm{B} / \mathrm{B}$} & (a) & 77 & 14 & 22 & 19 & 14 & 8 \\
\hline & (b) & 16 & 3 & 5 & 2 & 5 & 1 \\
\hline & (c) & 68 & 16 & 20 & 12 & 15 & 5 \\
\hline
\end{tabular}

Table 8: Numbers of firms and firm pairs playing the equilibrium strategy and the equilibrium for all possible subgames. (a) pairs in subgame, (b) pairs in equilibrium, (c) firms playing the equilibrium strategy, (d) non-subsidized firms playing the equilibrium strategy, (e) subsidized firms playing the equilibrium strategy.

negative inequality from 310 to 170 by choosing 20 instead of 15 . Thus, even moderate inequality aversion of both $i$ and $j$ implies outputs $q_{i}=20$ and $q_{j}=24$.

One might argue that for the individual decisions in the asymmetric subgames, deviations from the prediction were only possible in one direction. However, our above interpretation of the aggregate data is in line with the decisions of individual pairs in single periods (see Table 8, which also shows the most individual deviations in the asymmetric subgames). In total there were 124 asymmetric subgames. Only $16(12.9 \%)$ of these resulted in the equilibrium quantities $\left(q_{i}=15, q_{j}=28\right)$ while $22(17.8 \%)$ of the pairs played the combination $\left(q_{i}=20, q_{j}=24\right)$. Analyzing the data for the two firms separately shows that 44 $(35.5 \%)$ of the non-subsidized firms chose the equilibrium quantity while 59 (47.6 \%) chose $q_{i}=20$. Of the subsidized firms, $43(34.7 \%)$ chose the equilibrium quantity while $42(33.9 \%)$ chose $q_{j}=24$. In contrast, in the 77 symmetric subgames with both firms subsidized, $16(20.8 \%)$ of the pairs played the equilibrium strategy and $68(44.2 \%)$ of the individuals chose the equilibrium output. In the 99 symmetric subgames 


\begin{tabular}{|c|c|c|}
\hline Theory & don't subsidize & subsidize \\
\hline don't subsidize & $80.00,80.00$ & $52.00,96.00$ \\
\hline subsidize & $96.00,52.00$ & $58.00,58.00$ \\
\hline Experimental data & don't subsidize & subsidize \\
\hline don't subsidize & $80.41,80.41$ & $62.83,77.77$ \\
\hline subsidize & $77.77,62.83$ & $61.86,61.86$ \\
\hline
\end{tabular}

Table 9: Governments' expected payoffs, theory (top) and experimental data (bottom)

with none of the firms being subsidized even 38 (38.4\%) of the pairs ended up at the equilibrium and $117(59.1 \%)$ of the individuals chose the equilibrium output. Thus, it does not seem to be the case that subjects were unable to figure out the equilibrium, rather they seem unwilling to play it in the asymmetric subgames.

We saw that subjects acting as firms do not conform to the equilibrium prediction in the asymmetric subgames. Obviously, this must have consequences for the governments. We analyze the impact firm behavior has on governments by computing the ex-post realized payoffs of the governments in the four main treatments. ${ }^{10}$ The top of Table 9 shows the reduced government game given subgame-perfect behavior of firms. This is the normal prisoners' dilemma with "subsidize" being the dominant strategy. However, the payoff table of the governments that results from experimental firm behavior (see the bottom part in Table 9) shows that subsidizing ceases to be a dominant strategy. In fact, "don't subsidize" is now the dominant strategy. The non-subgame perfect behavior of the firms resolves the prisoners' dilemma for the governments. Given actual firm behavior, it is rational for governments not to subsidize.

\footnotetext{
${ }^{10}$ This is based on data from periods 6-10. Qualitatively, the same picture results for all five treatments separately. Including data from earlier periods also shows a similar, though less pronounced, picture.
} 


\section{Conclusions}

In this paper, we have reported on experiments designed to test the model of strategic trade policy as developed by Brander and Spencer (1985). Our data are not consistent with the theoretical prediction. Governments subsidize firms in too few cases to give conclusive evidence in favor of the theory. Over time, the number of subsidy decisions decreases, again suggesting a departure from the prediction. At the firm level, we found that the subgame perfect prediction fails in subgames in which one firm is subsidized while the other is not. This failure might be attributed to inequality aversion. Given firms' decisions, governments' reluctance to subsidize is rational.

We have isolated the strategic incentives in a setup where the Brander and Spencer (1985) theory should work best and have abstracted from any confounding factors that could be present in the field. Hence our results cast at least some doubts on the theory's relevance for field settings. We see the burden of proof on the part of the proponents of the theory to argue why in the presence of confounding factors the prediction based purely on the strategic situation should match the results more closely than in the isolated setup studied here.

Our results can be compared with related experimental studies. On the one hand, our results are in line with the studies on quantity competition in oligopoly by Huck et al. (2000, 2001a,b). Closely related is the work of Huck et al. (2000), which analyzes strategic delegation in a Cournot duopoly. Their analysis is based on the work of Fershtman and Judd (1987) and Sklivas (1987). While the strategic situation of these models is equivalent to the Brander and Spencer (1985) model, our experiments differ in the design and (partly) in the results to those of Huck et al. (2000). While the differences in design make a direct comparison of the results impossible, it appears that the theory is even more rigorously rejected in that paper. Huck et al. (2001a,b) analyze Stackelberg duopolies. They find considerable deviations from the subgame perfect equilibrium prediction as the empirical response function of the Stackelberg followers was partly upward sloping. As in this paper, inequality aversion seems to be the explanation for this behavior. A second parallel to this paper is that the behavior of the second movers heavily influences that of the first movers. In Huck et al. (2001a), the roles of the Stackelberg leader and follower were exogenously assigned. The follower behavior led to significant reductions in the outputs of the Stackelberg leaders. In Huck et 
al. (2001b), Stackelberg leader/follower equilibria are predicted to emerge endogenously in a model with two production periods, but there was no such evidence of endogenous Stackelberg leadership in the data. ${ }^{11}$

On the other hand, fairness considerations seem to be quite influential in our results when compared to a frequently observed effect in experimental economics. When experiments are framed as markets, fairness and inequality considerations usually have a much smaller impact than in experiments with a neutral design (Hoffman et al., 1994; Francicosi et al., 1995). Of course, we cannot exclude the possibility that if terms like "firm", "market", or "government" were not used, fairness and inequality considerations would be even stronger in our data. However, given our market labelling, the fairness effects do seem to be rather strong.

We see two interesting avenues for future research here. First, it would seem interesting to extend our research to a case in which firms are asymmetric anyway, e.g., due to differences in marginal cost (Neary, 1994). It might be that the kind of inequality aversion we observe is less pronounced in such games because there already exist asymmetries which may be economically justified. Another extension would be to allow for larger strategy spaces. Possibly such extended strategy spaces would give rise to more subsidy decisions since subjects no longer have to focus on the extreme cases. In addition, firms could then deviate in both directions in the asymmetric subgames. However, this design would also be considerably more complex, so it seems doubtful whether a clear picture would emerge in the data.

\section{References}

[1] Ansic, D. (1995): Note: A Pilot Experimental Test of Trade Hysteresis, Managerial and Decision Economics, 16, 85-91.

[2] Arvan, L. (1991): Flexibility versus Commitment in Strategic Trade Policy under Uncertainty - A Model of Endogenous Policy Leadership, Journal of International Economics, 31, 341-355.

\footnotetext{
${ }^{11}$ Models which attempt to endogenize the order of moves in oligopoly go back to Hamilton and Slutsky (1990). For applications to strategic trade policy, see Arvan (1991) and Collie (1994).
} 
[3] Baldwin, R. and Krugman, P. (1988): Market Access and Competition: A Simulation Study of 16K Random Access Memories, in: Feenstra, R. (ed.), Empirical Research in Industrial Trade, Cambridge: MIT Press.

[4] Bolton, G. and Ockenfels, A. (2000): ERC - A Theory of Equity, Reciprocity and Competition, American Economic Review, 90, 166-93.

[5] Brander, J.A. (1995): Strategic Trade Policy, in: Grossman, G. and Rogoff, K. (eds.), Handbook of International Economics, Vol. III, Amsterdam: Elsevier Science.

[6] Brander, J.A. and Spencer, B. (1985): Export Subsidies and International Market Share Rivalry, Journal of International Economics, 16, 83-100.

[7] Collie, D.R. (1994): Endogenous Timing in Trade Policy Games: Should Governments Use Countervailing Duties?, Weltwirtschaftliches Archiv, 130, 192-209.

[8] Cooper, R., DeJong, D.V., Forsythe, R. and Ross, T.W. (1996): Cooperation without Reputation: Experimental Evidence from Prisoner's Dilemma Games, Games and Economic Behavior, 12, 187218.

[9] Davis, D. and Holt, Ch. (1993): Experimental Economics, Princeton University Press.

[10] Dixit, A. (1988): Optimal Trade and Industrial Policy for the U.S. Automobile Industry, in: Feenstra, R. (ed.), Empirical Research in Industrial Trade, Cambridge: MIT Press.

[11] Eaton, J. and Grossman, G.M. (1986): Optimal Trade and Industrial Policy under Oligopoly, Quarterly Journal of Economics, 101, 383-406.

[12] Engelmann, D. and Strobel, M. (2002): Inequality Aversion, Efficiency, and Maximin Preferences in Simple Distribution Experiments, MERIT-Infonomics Research Memorandum, 2002-013, University of Maastricht.

[13] Fehr, E. and Schmidt, K. (1999): A Theory of Fairness, Competition, and Cooperation, Quarterly Journal of Economics, 114, 817-868. 
[14] Fershtman, C. and Judd, K.L. (1987): Equilibrium Incentives in Oligopoly, American Economic Review, 77, 927-940.

[15] Fischbacher, U. (1999): Z-Tree, Zurich Toolbox for Readymade Economic Experiments, Working paper Nr. 21, Institute for Empirical Research in Economics, University of Zurich.

[16] Franciosi, R., Kujal, P., Michelitsch, R., Smith, V., and Deng, G. (1995): Fairness: Effects on Temporary and Equilibrium Prices in Posted-Offer Markets, The Economic Journal, 105, 938-950.

[17] Grossman, G.M. (1990): Promoting New Industrial Activities: A Survey of Recent Arguments and Evidence, OECD-Economic Studies, 14, 87-125.

[18] Hamilton, J.H. and Slutsky, S.M. (1990): Endogenous Timing in Duopoly Games: Stackelberg or Cournot Equilibria, Games and Economic Behavior, 2, 29-46.

[19] Hoffman, E., McCabe, K., Shachat, K., and Smith, V. (1994): Preferences, Property Rights, and Anonymity Bargaining Experiments, Games and Economic Behavior, 7, 346-380.

[20] Holt, C.H. (1985): An Experimental Test of the Consistent-Conjectures Hypothesis, American Economic Review, 75, 314-325.

[21] Huck, S., Müller, W. and Normann, H.-T. (2000): Strategic Delegation in Experimental Markets, mimeo, Humboldt-Universität zu Berlin.

[22] Huck, S., Müller, W. and Normann, H.-T. (2001a): Stackelberg beats Cournot - On Collusion and Efficiency in Experimental Markets, The Economic Journal, 111, 113-125.

[23] Huck, S., Müller, W., and Normann, H.-T. (2001b): To Commit or not to Commit - Endogenous Timing in Experimental Duopoly, Games and Economic Behavior, 38, 240-264.

[24] Krishna, K., Hogan, K. and Swagel, P. (1994): The Non-Optimality of Trade Policies: The U.S. Automobile Industry Revisited, 1979-1985, in: Krugman, P. and Smith, A. (eds.), Empirical Studies of Strategic Trade Policy, Chicago: University of Chicago Press. 
[25] Krugman, P. (1993): The Narrow and the Broad Arguments for Free Trade, American Economic Review, 83, 362-366.

[26] Maggi, G. (1996): Strategic Trade Policies with Endogenous Mode of Competition, American Economic Review, 86, 237-258.

[27] Neary, J.P. (1994): Cost Asymmetries in International Subsidy Games: Should Governments Help Winners or Losers?, Journal of International Economics, 37, 197-218.

[28] Noussair, C.N., Plott, C., and Riezman, R.G. (1995): An Experimental Investigation of the Patterns of International Trade, American Economic Review, 85, 462-491.

[29] Noussair, C.N., Plott, C., and Riezman, R.G. (1997): The Principles of Exchange Rate Determination in an International Finance Experiment, Journal of Political Economy, 822-862.

[30] Plott, C. (1982): Industrial Organization Theory and Experimental Economics, Journal of Economic Literature, 20, 1485-1527.

[31] Sklivas, S. D. (1987): The Strategic Choice of Management Incentives, Rand Journal of Economics, $18,452-458$.

[32] Smith, V. (1982): Microeconomic Systems as an Experimental Science, American Economic Review, $72,923-955$.

\section{Appendix: Instructions (Translation)}

\section{[TREATMENT RANDSUB]}

Please read these instructions carefully. Do not talk to your neighbors during the course of the experiment. Raise your hand if you have any questions. We will then come to your booth.

In this experiment you will have to make decisions repeatedly. By making these decisions you can earn money. How much you earn depends on your decisions and on the decisions of three other participants. All participants receive the same instructions. 
You will remain anonymous to us and to the other participants.

You are in a market with two firms. The firms are located in two different countries. The market for the good that the firms supply is in a third country. It is thus an export market from the perspective of the firms.

The conditions under which the firms produce are influenced by the governments in the two countries. That is, the firms can be subsidized by the governments of their respective country [POLICY TREATMENTS: Precisely, the governments can choose from different economic policies]. (how this works exactly will be described below). You will make decisions for a government or for a firm.

The experiment runs over 10 rounds. In each of the rounds the sequence of decisions is as follows. At the beginning of each round the governments decide whether or not to subsidize the firms. [POLICY TREATMENTS: ... choose their economic policies.] These decisions will be publicly announced afterwards. Then the firms decide upon the quantity they want to supply.

The subsidy [POLICY TREATMENTS: policy] and quantity decisions determine the profits of the firms and the revenues of the governments as can be seen in the five accompanying payoff tables.

Consider first the governments' decisions. There are two options: to subsidize or not to subsidize. This determines the conditions for the firms' profits as follows.

[Policy TREATMENTS: There are two options: Economic Policy A or economic policy B. The economic policy determines the conditions for the firms' profits as follows. Subsequently replace subsidy decisions with policy decisions, subsidy with Policy B and no subsidy with Policy A]

If neither governments subsidizes, the first payoff table is relevant for the firms. If, from the perspective of a firm, the own government has decided to subsidize, while that of the other country has not, the second table is relevant. If only the government of the other country has decided to subsidize it is the other way round, the third table is relevant. Finally, if both have decided to subsidize, the fourth table is relevant.

Consider now the firms' decisions. Knowing the subsidy decisions, the firms choose the quantity of the good they produce and sell. There are four possible quantities: 1, 2, 3, and 4. Depending on the two quantities, the firms' profits and the governments' revenues result according to the relevant tables. 
A firm's profit table has the following form. Your own quantity decision (quantity 1, 2, 3, or 4) is noted at the left of each row of the table, the quantity decision of the other firm at the top of each column. Since there are four possible quantities, there are sixteen possible combinations or cells in the table.

The profits are computed as follows. There are two numbers in each of the sixteen cells. On the left is the own profit, on the right is the other firms' profit.

The table for the government has the same structure. Depending on the quantity decisions of the firms, one of the sixteen cells of the revenue table is relevant. Here, again, the own government's revenue is on the left and the other governments' revenue is on the right.

Before the start of the experiment, we will use an example to explain the tables once again in detail.

Your payoff at the end of the experiment results from the profits or revenues you have earned during the ten rounds. For payoffs in Deutschemarks the firms' profits will be exchanged at a rate of 200 points $=1 \mathrm{DM}$, the governments' revenues at a rate of 40 points $=1 \mathrm{DM}$.

Finally, consider once again the exact sequence of events. As soon as the first round starts, both governments decide whether or not they will subsidize their firm. As soon as this is done all participants in one market will be informed about both decisions. Then both firms have to make their first quantity decisions (knowing the subsidy decisions and hence the relevant profit table). As soon as these are made, all participants are again informed about both decisions. In addition, all participants are informed about their own profit or revenue that results from the decisions.

Then a new round starts and decisions can be made anew.

Each participant will keep the role (government or firm) over the ten rounds. A government will stay with the same firm for all ten rounds. The second government-firm pair, with whom you interact in the market, will be randomly selected anew in each round.

[FIX TREATMENTS: Furthermore, the second government-firm pair, with whom you interact in the market, will always be the same.] 
CERGE-EI

P.O.BOX 882 Politických vezòù 7

11121 Prague 1

Czech Republic http://www.cerge-ei.cz 